\title{
Inhibiting Effects of Vegetation on the Characteristics of Runoff and Sediment Yield on Riparian Slope along the Lower Yellow River
}

\author{
Yifan Zhang ${ }^{1,2}$, Qinghe Zhao ${ }^{1,2, * \mathbb{D}}$, Zihao Cao ${ }^{1,3}$ and Shengyan Ding ${ }^{1,2, *}$ \\ 1 College of Environment and Planning, Henan University, Kaifeng 475004, China \\ 2 Key Laboratory of Geospatial Technology for the Middle and Lower Yellow River Regions (Henan University), \\ Ministry of Education, Kaifeng 475004, China \\ 3 Faculty of Geographical Science, Beijing Normal University, Beijing 100875, China \\ * Correspondence: zhaoqinghe@henu.edu.cn (Q.Z.); syding@henu.edu.cn (S.D.)
}

Received: 22 May 2019; Accepted: 3 July 2019; Published: 4 July 2019

\begin{abstract}
Riparian vegetation plays a vital role in soil and water conservation and river health maintenance. However, its inhibiting effects on water and soil loss are limited by different factors, such as slope gradient, vegetation coverage and their interaction. Therefore, this study quantified the inhibiting effect of riparian vegetation on the runoff, sediment and hydraulic characteristics of overland flow, and assessed its relative contribution to slope gradient. Specifically, we selected a riparian slope along the lower Yellow River as a case, and used a field-simulated rainfall experiment under specific rainfall intensity $(90 \mathrm{~mm} / \mathrm{h})$, different vegetation coverage $(0 \%, 15 \%$ and $30 \%)$ and slope gradients $\left(5^{\circ}, 10^{\circ}, 15^{\circ}\right.$ and $\left.20^{\circ}\right)$. The results showed that the presence of vegetation can reduce the slope runoff rate and erosion rate. However, greater slope gradients can result in a lowering of the inhibiting effects of riparian vegetation on sediment yield. There was a critical value of vegetation coverage for inhibiting eroded sediments which was influenced by the degree of slope gradient. At $15 \%$ vegetation coverage, vegetation inhibited the slope sediment yield greatly at a slope gradient of less than $8^{\circ}$; while at $30 \%$ vegetation coverage, vegetation greatly inhibited the slope sediment yield at slope gradients $<11^{\circ}$. Hydraulic characteristics were closely related to the slope gradient and vegetation coverage by the power function. Grey correlation analysis revealed that, with increasing of vegetation coverage, the effect of stream power on slope sediment yield decreased, while the effect of the friction coefficient on slope sediment yield increased. In summary, riparian vegetation can effectively inhibit slope runoff and sediment yield, but its inhibiting effect is notably affected by slope gradient.
\end{abstract}

Keywords: inhibiting effect; slope gradient; vegetation coverage; slope erosion process; riparian slope

\section{Introduction}

As an important transitional zone between rivers and terrestrial ecosystems, the riparian zone acts as a corridor, filter and barrier, and its effective management is an important guarantee for maintaining the stability and health of river and terrestrial ecosystems [1,2]. In recent years, due to natural environmental changes in climate, channel morphology, flood cycles and beach structures, and human activities such as urban expansion, large-scale engineering construction, and agricultural and livestock development, the structure and function of the riparian ecosystem has been severely impaired [3,4]. Therefore, the restoration and maintenance of riparian ecosystem function has become a central and urgent need in geographical and ecological research [3]. At present, most researchers focus on the corridor [5], buffer [6] and revetment functions [7] of the riparian ecosystem, and carried 
out studies on riparian structural features [8,9], biodiversity conservation and influencing factors [5], prevention and control of non-point source pollution [6] and riparian maintenance and soil erosion prevention $[7,10,11]$. However, compared to riparian biodiversity and agricultural non-point source pollution control mechanisms, soil erosion control of the riparian zone remains poorly understood.

Riparian vegetation, which is the last barrier for the highland runoff and sediment transport to the river in the basin, plays an important role in intercepting, filtering and depositing the soil particles of surface runoff, stabilizing river banks and preventing river bank erosion and collapse by enhancing infiltration, reducing runoff and flow velocity and improving soil corrosion resistance $[7,12]$. Previous studies have explored the relationship between riparian vegetation and soil and water conservation specifically focusing on vegetation type, coverage, root system [13-15], structural characteristics of vegetation [16,17], distribution and arrangement of vegetation [18] and the coupled models of vegetation pattern and the soil erosion process [19]. For example, Srivastava et al. [13] and Xia et al. [14] analyzed the effects of riparian vegetation on slope erosion by creating field simulated rainfall or performing runoff scouring experiments to determine the effect of presence or absence of vegetation on slope erosion. However, the interaction and relative contribution between the vegetation coverage and slope gradient were not taken into consideration in these studies when investigating the inhibiting effects of riparian vegetation on slope runoff and sediment yield; meanwhile the quantitative evaluation of the relevant factors in soil erosion process should also be considered. Slope gradient, as a control factor of soil erosion, determines the runoff scouring and transporting capacity [20]. Studies have shown that, within a certain range, the greater the slope gradient is, the higher the soil erosion will be [21,22]. For example, Zhao et al. [23] found that the increase in slope gradient in the red soil region of Southern China could weaken the effects of vegetation in inhibiting soil erosion. However, when the slope gradient reaches a certain degree or critical value, the relationship between slope gradient and soil erosion will be reversed [24]. The critical slope gradient is defined differently in each study. For instance, Defersha et al. [25] who conducted rainfall experiments based on three types of soil with three different slope gradients $\left(5^{\circ}, 25^{\circ}\right.$, and $\left.45^{\circ}\right)$ in the highlands of Ethiopia showed that the amount of erosion gradually decreased once the slope gradient reached its peak at $25^{\circ}$. Liu et al. [26] investigated slope runoff and sediment yield under natural rainfall conditions and found that the critical gradient lay between $15^{\circ}$ and $20^{\circ}$. These studies showed that the effects of slope gradient on the erosion slope is complex. The critical slope gradient in the slope erosion process changes due to factors such as erosion pattern, soil type, vegetation status and boundary conditions. Therefore, further studies are needed to understand the effects of slope gradient on vegetation that inhibits runoff and sediments.

The lower region of the Yellow River is an important part of the Yellow River Basin and one of China's major grain producing areas. Due to population growth, increased food demand and continued expansion of agricultural land, most of the land in its riparian buffer zone has been cultivated, and the maintenance and sustainable play of the ecosystem services of the riparian buffer ecosystem is under substantial threat. In particular, its soil and water conservation and non-point source pollution control functions gradually degenerated or disappeared under the influence of vegetation damage caused by human behavior [27-30].

Therefore, selecting the riparian slope along the lower Yellow River as a case, based on a field-simulated rainfall experiment, Grey correlation and relative contribution analyses, this study aimed to analyze:

(1) the characteristics of riparian vegetation to block slope runoff and sediment,

(2) the influence of riparian vegetation on hydraulic characteristics of overland flow,

(3) the effects of the slope gradient on the efficiency of riparian vegetation for inhibiting slope erosion, and

(4) the relative contribution of slope gradient and vegetation coverage in the slope erosion process.

The results of this study can provide a theoretical and practical basis for ecological restoration and reconstruction of the riparian vegetation buffer zone in China. 


\section{Materials and Methods}

\subsection{Study Area}

The area studied is located in Zhongmu County (Figure 1), Henan Province, and is an epitome of the agricultural landscape in the lower Yellow River plain, one of China's grain base counties. The area belongs to the warm temperate continental semi-humid monsoon climate. Rainfall mostly occurs in summer and autumn, and the annual precipitation is between 550 to $650 \mathrm{~mm}$ characterized by considerable annual variation and uneven spatial distribution. In recent years, the number of rainy days has decreased, heavy rain fall increased, and drought and flood disasters have become more common $[27,28]$. The soil type of this area is dominated by fluvo-aquic soil and yellow cinnamon soil [28]. The plant species in the study area mainly belong to the family Gramineae, Compositae, Leguminosae and Brassicacea [27].
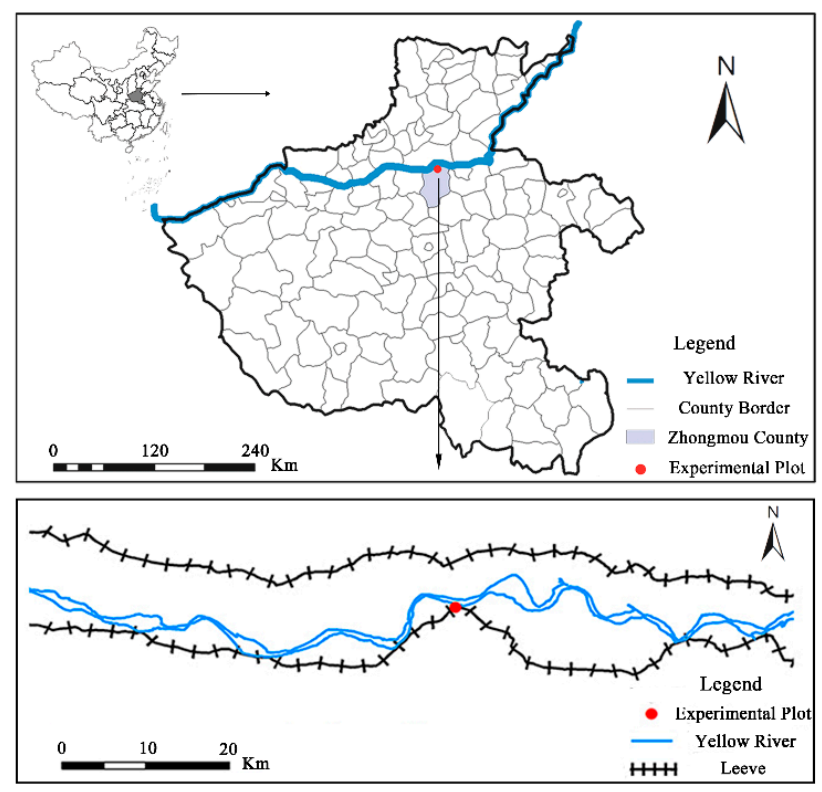

Figure 1. Location of the study area and experiment plots.

The riparian slope area near the Jiubao village was selected to carry out the experiment. The selected study site $\left(34^{\circ} 55^{\prime} 52.15^{\prime \prime} \mathrm{N}, 114^{\circ} 1^{\prime} 21.51^{\prime \prime} \mathrm{E}\right)$, which is characterized by a predominantly annual herbaceous plant vegetation and by rainfall-runoff, grazing, farming, recreation, human disturbances and land use (upward slopes for farmland and woodland, downward slopes for area of water level fluctuations and Yellow River waters), is valid representation of the riparian zone.

\subsection{Research Framework and Experiment Design}

The inhibiting mechanism of riparian vegetation on slope erosion is of great significance for the maintenance of soil and water conservation in the riparian zone. In this study, using a field-simulated rainfall experiment, Grey correlation and relative contribution analyses, we studied the characteristics of runoff and sediment yield of the lower Yellow River slope that was inhibited by vegetation, and its relationship with hydraulic characteristics under specific rainfall intensity, different vegetation coverage and slope gradients. We also investigated the influence and relative contribution of slope gradients and vegetation coverage on how vegetation may reduce or inhibit slope erosion. The research framework of this study is shown in Figure 2. 


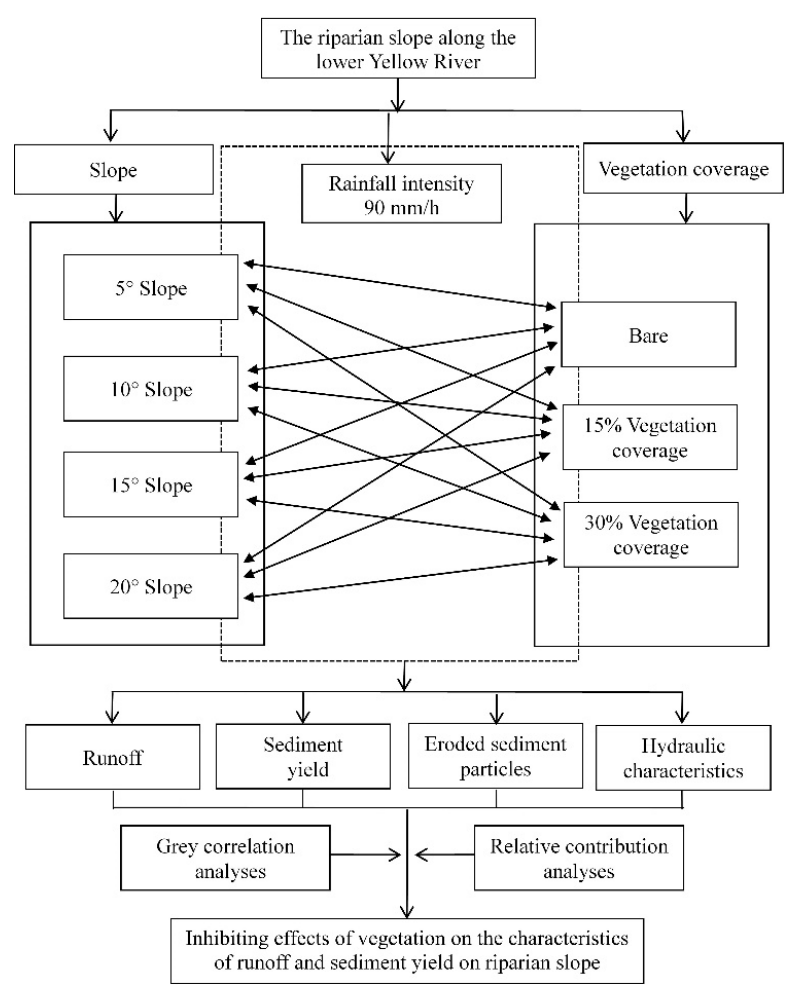

Figure 2. The research framework.

According to the research framework, the field simulated rainfall experiment was carried out using a side-spray simulated rainfall device (JLC-RY1, Licheng Automation Equipment Limited Company, Jinzhou City, China). The rainfall support was placed on the outside of the experimental plot (the bracket was fixed in the soil), $0.25 \mathrm{~m}$ from the edge of the plot. The rainfall nozzle was perpendicular to the plot with a rainfall height of $2 \mathrm{~m}$, an effective rainfall area of $1.5 \mathrm{~m} \times 3 \mathrm{~m}$, and a good raindrop atomization effect. In order to reduce the impact of the wind on the outcome of our study, a canvas was set on the windward side of the rainfall support. The experimental plot size was $1 \mathrm{~m} \times 3 \mathrm{~m}$ (length $\times$ width), the upward area of the plot was a storage tank, and the V-shaped collecting trough was placed at the tail for collecting sediments and runoff (Figure 3). The water was continuously supplied to the storage tank by a high-pressure automatic water supply tower.

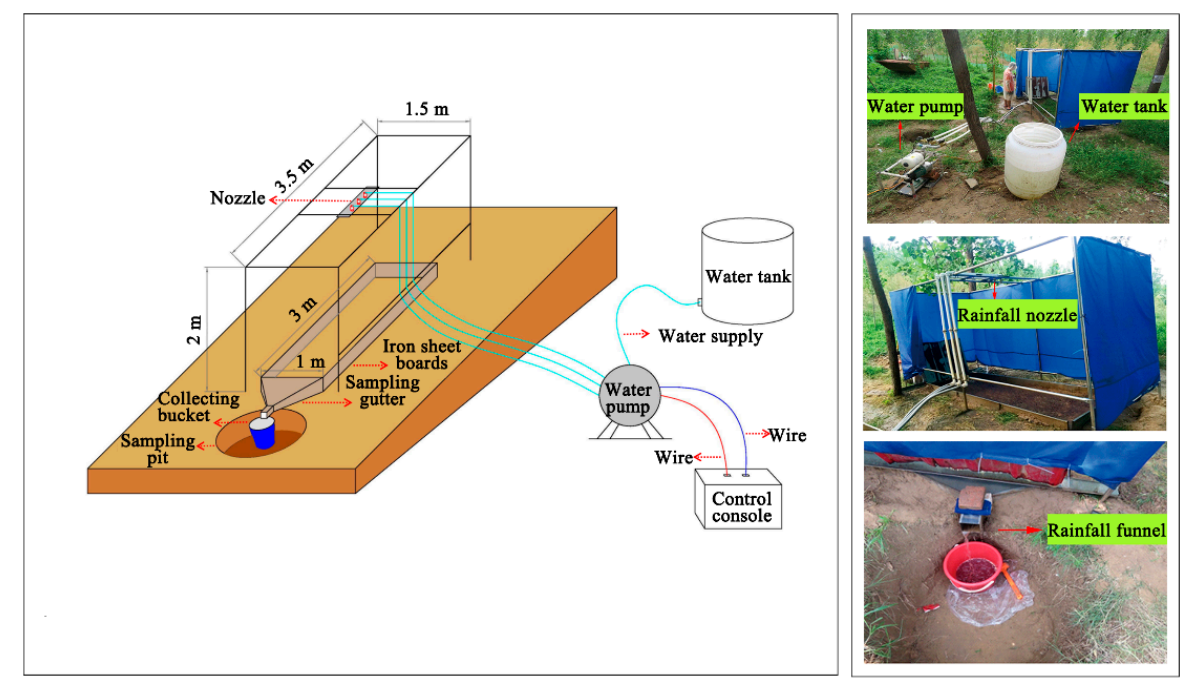

Figure 3. Schematic diagram of the rainfall experiment setup. 
Based on previous studies of field survey results and rainfall data [28] on the topography and vegetation of the Zhongmu section of the lower Yellow River, four slope gradients $\left(5^{\circ}, 10^{\circ}, 15^{\circ}\right.$ and $\left.20^{\circ}\right)$, three vegetation coverage $(0 \%, 15 \%$ and $30 \%)$, and one rainfall intensity $\left(90 \mathrm{~mm} \cdot \mathrm{h}^{-1}\right)$ parameter were set. Thus, a total of 12 treatments were conducted; each treatment lasted $30 \mathrm{~min}$ and was repeated twice. Meanwhile, the vegetation and underlying surface conditions in the plot were similar (Table 1). Vegetation in the plot was randomly trimmed and was then photographed with a camera (Canon SX60 HS) at a distance of $2 \mathrm{~m}$ perpendicular to the experimental plot. The vegetation coverage was then extracted using Photoshop CS4 software and this process was repeated until the error of preset vegetation coverage was $<0.5 \%$.

Table 1. Soil physical characteristics and main plant of the experimental slopes.

\begin{tabular}{|c|c|c|c|c|c|c|}
\hline \multirow{2}{*}{$\begin{array}{c}\text { Slope Gradient } \\
\left({ }^{\circ}\right)\end{array}$} & \multirow{2}{*}{$\begin{array}{c}\text { Soil Water Content } \\
(\%)\end{array}$} & \multirow{2}{*}{$\begin{array}{l}\text { Soil Bulk Density } \\
\left(\mathrm{g} \cdot \mathrm{cm}^{-3}\right)\end{array}$} & \multicolumn{3}{|c|}{ Particle Size Distribution of Soil } & \multirow{2}{*}{ Main Plant } \\
\hline & & & Clay $(\%)$ & Silt (\%) & Sand $(\%)$ & \\
\hline 5 & 22 & 1.60 & 0.71 & 57.67 & 41.62 & Setaria viridis \\
\hline 10 & 18 & 1.57 & 0.68 & 48.23 & 51.09 & Setaria viridis \\
\hline 15 & 19 & 1.55 & 0.47 & 58.27 & 41.29 & Setaria viridis \\
\hline 20 & 20 & 1.59 & 0.44 & 52.85 & 46.71 & Setaria viridis \\
\hline
\end{tabular}

\subsection{Experiment Process}

The rainfall intensity was repeatedly calibrated before the rainfall experiment until the error rate compared to the pre-set value was less than $2 \%$. To ensure that the initial conditions were consistent, the slope was pre-rained, and the rainfall was controlled to the extent that the soil surface was fully saturated but no runoff was generated. The rainfall experiment was started after the surface water infiltration of the slope surface was completed. The rainfall lasted for a duration of $30 \mathrm{~min}$, and the time for runoff initiation and duration of runoff recession were recorded for the study. The runoff samples were taken every minute for the first $5 \mathrm{~min}$, and were then taken every $5 \mathrm{~min}$ for the remaining $25 \mathrm{~min}$. The slope flow velocity was measured by the $\mathrm{KMnO} 4$ coloration method and measured at the same time interval. Then, the average value was multiplied by a correction factor of 0.67 for the average slope flow velocity according to a previous study [31]. After the rainfall, the total amount of runoff sediment was weighed, separated and dried at $105^{\circ} \mathrm{C}$ until a constant sediment weight was reached. The quality of the dried sediment was the amount of sediment produced and the total amount of runoff sediment minus the amount of sediment produced was then referred to as runoff yield. The runoff and erosion rate were defined as the amount of runoff and sediment yield per unit area during rainfall.

\subsection{Data Analysis}

The stream power $(\omega)$ characterizes the energy consumed by the runoff for erosion and can eliminate the error caused by the non-uniformity of the slope runoff depth. Therefore, the stream power was used to calculate the runoff erosivity as follows [27,32]:

$$
\omega=\frac{\gamma Q J}{B t}
$$

where $\omega$ is the stream power $\left(\mathrm{N} \cdot \mathrm{m}^{-1} \cdot \mathrm{s}^{-1}\right) ; \gamma=9800\left(\mathrm{~N} \cdot \mathrm{m}^{-3}\right) ; J$ is the hydraulic gradient $\left(\mathrm{m} \cdot \mathrm{m}^{-1}\right)$, and its value is replaced by the positive value of the slope gradient; $Q$ is the total runoff volume $\left(\mathrm{m}^{3}\right) ; t$ is the runoff sampling interval ( $\mathrm{min}) ; B$ is the width of water-crossing section $(\mathrm{m})$.

The Darcy-Weisbach friction coefficient $(f)$ reflects the ability of external factors (rainfall, vegetation, soil texture, etc.) to block the runoff [33]:

$$
f=\frac{8 g h J}{U^{2}}
$$


where $f$ is the Darcy-Weisbach friction coefficient; $g$ is the gravitational acceleration $\left(\mathrm{m} \cdot \mathrm{s}^{-2}\right) ; h$ is the runoff depth $(\mathrm{cm}) ; U$ is the flow velocity $\left(\mathrm{m} \cdot \mathrm{min}^{-1}\right)$; the other variables are described in the previous calculation.

In order to determine the effect of slope gradient on the riparian vegetation's ability to inhibit slope erosion and sediment yield, we used the relative contribution index to quantify the contribution of slope gradient and vegetation coverage to slope erosion and sediment yield [28]. The $5^{\circ}$ slope gradient was selected as baseline, and the amount of sediment change on the slope gradient $X^{\circ}\left(5^{\circ}\right.$, $10^{\circ}, 15^{\circ}, 20^{\circ}$ ) caused by the vegetation was calculated according to the following formula:

$$
I S Y_{s g}=S Y_{b l}\left(X^{o}\right)-S Y_{b l}\left(5^{o}\right)
$$

where $I S Y_{s g}$ is the change of sediment yield ( $\mathrm{g}$ ) caused by slope gradient, $S Y_{b l}$ is the sediment yield (g) of bare land.

$$
I S Y_{v c}=S Y_{v c}\left(X^{o}\right)-S Y_{v c}\left(X^{o}\right) \text {, }
$$

where $I S Y_{v c}$ is the change of sediment yield (g) caused by vegetation coverage, and $S Y_{v c}$ is the sediment yield $(\mathrm{g})$ under vegetation coverage.

$$
\begin{gathered}
I S Y_{t}=I S Y_{s g}+I S Y_{v c}, \\
R C I_{s g}=\frac{I S Y_{s g}}{I S Y_{t}}, \\
R C I_{v c}=\frac{I S Y_{v c}}{I S Y_{t}},
\end{gathered}
$$

where $I S Y_{t}$ is the total sediment yield $(\mathrm{g})$, and $R C I_{s g}$ and $R C I_{v c}$ are the relative contribution indexes of slope gradient and vegetation coverage to the sediment yield.

Taking the sediment yield with $15 \%$ vegetation coverage as control, the inhibiting effect of the plot slope was calculated after increasing the vegetation coverage as follows [27]:

$$
E=\frac{Y_{15 v}-Y_{30 v}}{Y_{15 v}}
$$

where $E$ is the inhibiting effect, $Y_{15 v}$ and $Y_{30 v}$ are the slope erosion at $15 \%$ and $30 \%$ vegetation coverage, respectively.

The enrichment rate $(E R)$ is the ratio of the eroded sediment particles with different particle sizes and background content of the tested soil particles [34]. In this study, the distribution of background soil and eroded sediment particle size which were classified according to the USDA soil particle size classification scheme were measured with a Malvern laser particle size analyzer (Mastersizer 3000). ER was calculated according to the following mathematical formula:

$$
E R_{i}=\frac{\text { Sed }_{i}}{\text { Soil }_{i}}
$$

where $E R_{i}$ represents the enrichment rate of the $i$-th particle size fraction, and $S_{e d}$ and $S_{i} i l_{i}$ represent the percentage of the $i$-th particle size fraction in the eroded sediment and the background soil, respectively. Compared to the background soil, $E R>1$ indicates that certain particle sizes are highly concentrated and enriched in the eroded sediment. While an $E R<1$ indicates that certain particle size is lower in the eroded sediment and that sedimentation occurs [34].

Grey correlation analysis quantitatively describes the correlation among various factors. We used Grey correlation analysis to explore and quantitatively assess the role of stream power and friction coefficient in the process of slope sediment yield characteristics.

According to the specific calculation steps of the Grey correlation analysis [35], the reference sequence and the objective sequence were determined and the sizing was eliminated. When the 
reference sequence is set to $Y_{0}(k)$, the comparison sequence is $Y_{i}(k), i=1,2,3,4,5, \ldots, m$, and the sequence length is $N$. The correlation coefficient $\gamma_{0 i}(k)$ and the correlation degree $\gamma_{0 i}$, was then calculated as follows:

$$
\gamma_{0 \mathrm{i}}=\frac{\operatorname{minmin}_{i \in m}\left|x_{0}(k)-x_{i}(k)\right|+\rho \operatorname{maxmax}_{i \in m}\left|x_{0}(k)-x_{i}(k)\right|}{\left|x_{0}(k)-x_{i}(k)\right|+\rho \operatorname{maxmax}_{i \in m}\left|x_{0}(k)-x_{i}(k)\right|},
$$

where $\left|x_{0}(k)-x_{i}(k)\right|$ is the sequence difference; $\rho$ is the distinguishing coefficient, set $\rho=0.5$.

$$
\gamma_{0 \mathrm{i}}=\frac{1}{\mathrm{n}} \sum_{k=1}^{n} \gamma_{0 i}(k)
$$

These indexes were analyzed and plotted using Excel 2010, SPSS 17.0 and Origin 9.1 software, respectively.

\section{Results and Discussion}

\subsection{Characteristics of Riparian Vegetation to Block Slope Runoff and Sediment Yield}

As shown in Figure 4, the runoff rate at different vegetation coverage increased rapidly with the increase of rainfall duration and gradually stabilized later, which could be related to soil crust caused by the initial rainfall $[22,36]$. On the non-vegetation slope side, raindrops dripped directly on the slope may result in aggregates being broken down and converted into fine silts, hence blocking soil voids and leading to the formation of crusts on the slope surface. The soil crust slowed down the infiltration and made the rainfall quickly runoff. As the rainfall continued, soil infiltration stabilized, and the rainfall became the main factor affecting runoff. As previously shown, most of the rainfall was converted into slope runoff, stabilizing the runoff rate [21,37]. However, the presence of vegetation can intercept rainfall splashes, delay the formation of soil crusts on the slope surface and maximize soil water storage [15]. Therefore, the increase in runoff rates on the vegetation slopes was less than that on bare slopes at the beginning of the rainfall. The runoff rate decreased with higher slope gradients under the same vegetation coverage. This is consistent with the slope runoff properties obtained by Chen et al. [38] and Zhang and Zheng [39] using model simulations and indoor rainfall experiments. In spite of this, the comparability of results between indoor and field rainfall experiments should be notable. On one hand, in indoor rainfall experiments it is difficult to simulate the complex underlying surface conditions that occur in field rainfall experiments, but they can help to better understand soil erosion mechanisms behind complex conditions. On the other hand, field rainfall experiments can well reflect the complex underlying surface conditions that occur in nature, but it is difficult to meet the strict requirements of repeated tests. Therefore, in many cases, they are complementary and comparable. Furthermore, some studies showed that there is a positive correlation between slope gradient and slope runoff [21], or there is a threshold for the impact of slope gradient on slope runoff [26,37], even though the slope gradient has no significant effect on slope runoff [22]. Since slope runoff involves other factors such as surface roughness, rainfall intensity and soil texture, as well as the setting of slope range and experimental methods [40], the relationship between slope gradient and slope runoff needs to be further evaluated. Using the same slope gradient, the runoff rate decreased with increasing vegetation coverage, indicating that the presence of vegetation can increase the soil infiltration rate $[41,42]$ and reduce surface runoff. The ability of vegetation to intercept rainfall and runoff increased with higher vegetation coverage. In addition, when the vegetation coverage increased from $15 \%$ to $30 \%$, the inhibiting effect of vegetation on the runoff rate was $27.24 \%, 24.09 \%$, $28.80 \%$ and $10.54 \%$ at different slope gradients. This indicates that the inhibiting effect of vegetation on the runoff rate decreases with a higher slope gradient. Thus, the increase of the slope gradient weakens the inhibiting effect of the vegetation. When the slope gradient is small, the effect of vegetation to intercept runoff was obvious, while no obvious effect was observed when the slope gradient was relatively greater. 

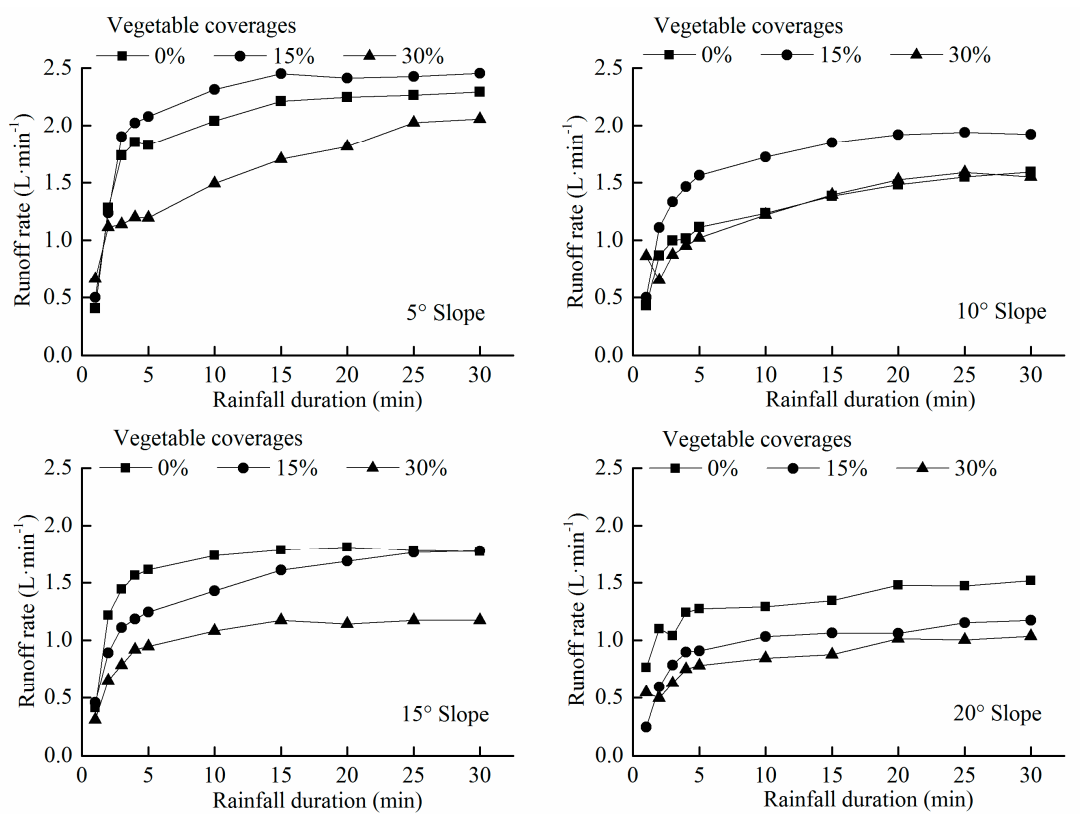

Figure 4. Influence of riparian vegetation on slope runoff rate under different slope gradients.

The effect of riparian vegetation on the slope erosion rate was similar to that of the runoff rate (Figure 5). At the early stage of rainfall (0-5 $\mathrm{min}$ ), the slope erosion rate showed a sharp increase at different vegetation coverages. This indicates that loose soil at the slope surface layer provides a large amount of transport material for the slope runoff with strong sediment transport capacity (low sediment content). It also resulted in a sharp increase in the slope erosion rate at the early stage of rainfall, at which time sediment transport was mainly limited by the runoff transport regime [43,44]. With increasing rainfall duration, the formation of slope crusts and a reduction of aided loose soil on the surface layer, slope runoff gradually changed from the transport-limiting regime to the detachment-limiting regime [43,44]; therefore, the slope erosion rate tended to be stable. This is similar to previous studies conducted on a red soil slope [39], loessial slope [22] and black soil slope [25]. However, the smoothing time of the slope erosion rate was different from that of previous studies, which might be due to the differences of vegetation coverage, slope gradient and soil texture between our study and previous studies. In addition, the average erosion rate in areas with different vegetation coverage reached its peak at $15^{\circ}$ before increasing and then decreasing later. Thus, according to the slope critical value assumption, the critical gradient of the slope erosion rate should be around $15^{\circ}$. This result is different from the proposed $20^{\circ}-25^{\circ}$ estimated by Zhang and Zheng [39] under $50 \mathrm{~mm} / \mathrm{h}$ rainfall intensity, suggesting that the critical gradient might be related to the rainfall intensity and may lead to an early peak of slope erosion rate. Under the same slope gradient, the erosion rate of the vegetation slope was smaller than that of the bare slope, and decreased with increasing vegetation coverage. This indicates that vegetation can hold soil and improve the slope's erosion resistance $[14,18]$. When the vegetation coverage increased from $15 \%$ to $30 \%$, the inhibiting effect of vegetation on the slope's erosion rate under different slope gradients was $69.39 \%, 49.55 \%, 11.88 \%$ and $7.05 \%$, respectively. This means that increases of the slope gradient weaken the vegetation's ability to reduce slope sediment yield. 

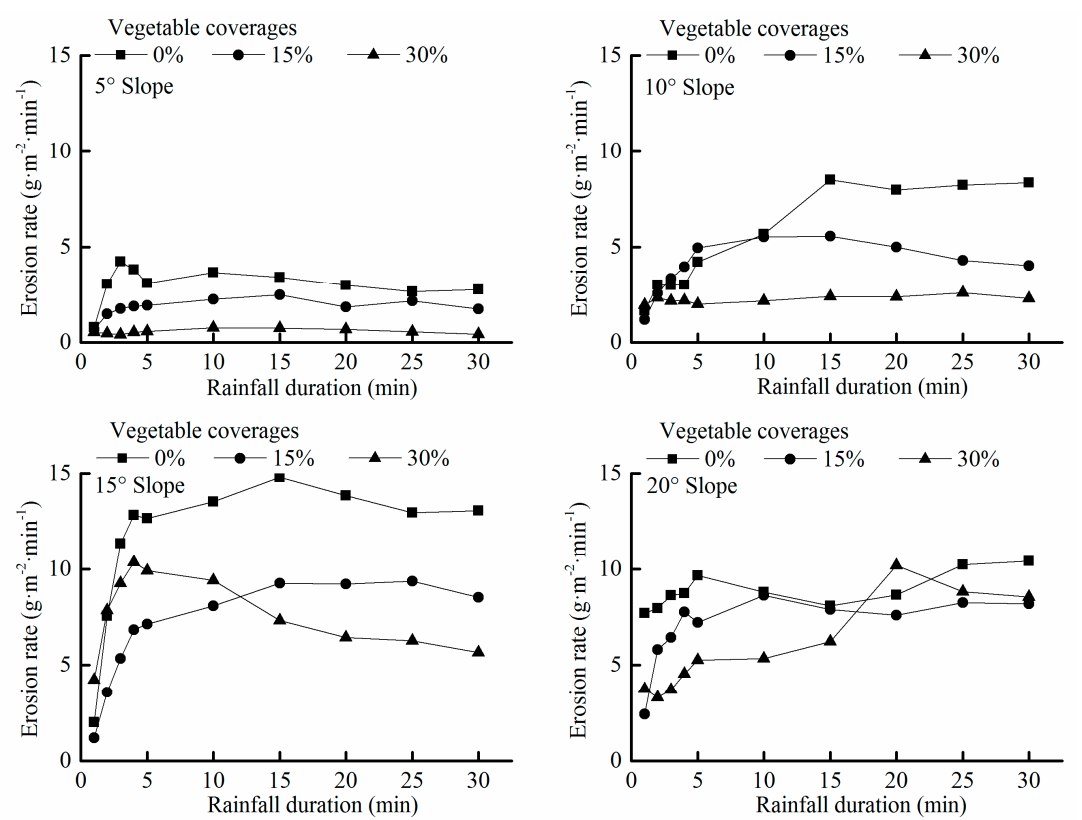

Figure 5. Impact of riparian vegetation on slope erosion rate under different slope gradients.

\subsection{Impacts of Riparian Vegetation on the Characteristics of Slope Erosion and Sediment Particles}

In our study, the sediment particle enrichment ratio (ER) was selected to investigate the sorting characteristics and transport mechanisms of the runoff of sediment particles during slope erosion. The results (Figure 6) show that the content of clay and fine silts increased greatly at the early stages of rainfall, indicating that clay and fine silts were preferentially eroded first in the slope erosion process. This was related to soil particle separation caused by raindrop splashes at the early stages of rainfall, which led to a bonding loss between soil particles. The rainfall promoted the dispersion of small particles into "suspended" or "semi-suspended" states, meaning they were able to be transported by the runoff, thereby increasing the content of fine silts in the eroded sediment [34,36]. Meanwhile, the average ERs of clay and fine silts were greater than one, which demonstrated that the runoff preferentially transported fine silts first. With increasing rainfall duration, the ability of the slope runoff to ablate soil increased and soil particles with a larger size were gradually separated and transported, meanwhile, the ER of sands and coarse silts gradually increased. At the middle stages of rainfall (from 10-25 $\mathrm{min}$ ), the driving force of the slope soil detachment process shifted from rainfall splatters to runoff erosion; at this time, the ER of clay and fine silts decreased. At the later stage of rainfall (from 25-30 min), the composition of sediments with different particle sizes was relatively stable, and the ER approached one. Under different vegetation coverage conditions, there was no obvious change in the size of the eroded sediments (mainly only clay and silts), which was due to a strong interception of vegetation on larger particles compared to small particles [45,46]. Of note is that the coarse silts and sands were enriched on the vegetation slope, which may be related to a larger particle size of the test soil, increased slope gradients which lead to the enhancement of the slope runoff transport capacity, and the sedimentation reduction of coarse silts and sands. For instance, changes in the coarse silt ER were not obvious when the slope gradient was less than $20^{\circ}$, but were enriched when the slope gradient was $20^{\circ}$. 

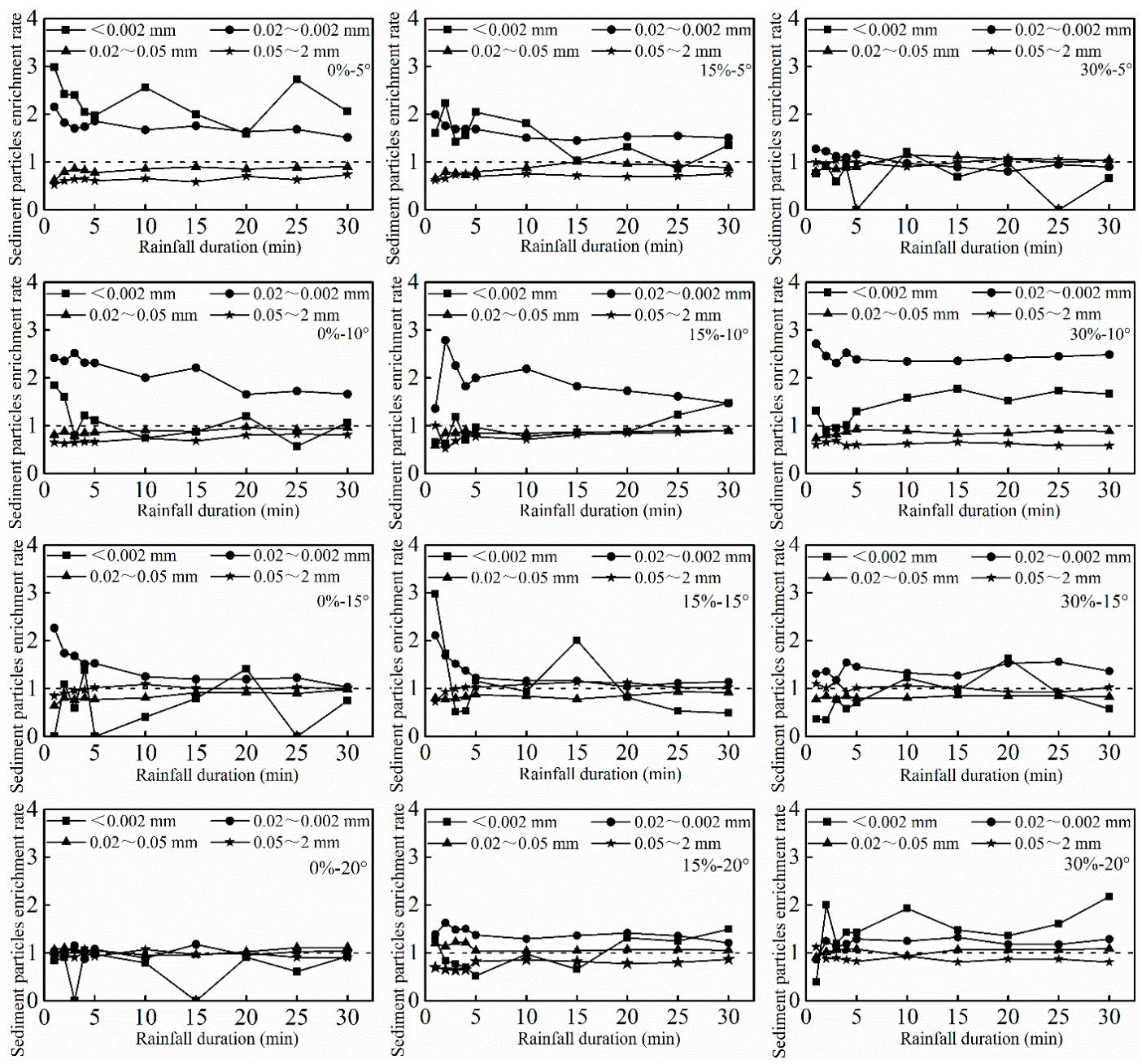

Figure 6. Effects of riparian vegetation on eroded sediment particles under different slope gradients. Note: The different treatments were represented by "coverage-slope gradient", such as $15 \%-10^{\circ}$, which means that the vegetation coverage is $15 \%$ and the slope gradient is $10^{\circ}$.

\subsection{Influence of Riparian Vegetation on Hydraulic Characteristics of the Slope}

As shown in Figure 7, stream power was enhanced with an increasing slope gradient. This can be explained by the fact that an increase of the slope gradient leads to an enhancement of the kinetic energy and potential energy of the runoff in vertical and horizontal directions and subsequently improves the slope runoff's scouring ability. In this study, the average stream power of the bare slope $\left(0.09-0.23 \mathrm{~N} \cdot \mathrm{m}^{-1} \cdot \mathrm{s}^{-1}\right)$ was larger than that of the vegetation slope $\left(0.07-0.19 \mathrm{~N} \cdot \mathrm{m}^{-1} \cdot \mathrm{s}^{-1}\right)$, indicating that vegetation coverage can effectively weaken the sedimentation capacity of the stream, and the stream power decreased with increasing vegetation coverage. When the vegetation coverage increased from $15 \%$ to $30 \%$, the inhibiting effect of vegetation on stream power at different slope gradients was $25.93 \%, 22.34 \%, 29.04 \%$ and $12.29 \%$, respectively. The inhibiting effects of vegetation on runoff erosivity decreased with an increase in the slope gradient, indicating that the effects of vegetation on reducing the sediment transport capacity of slope runoff was far less than that of the slope gradient on increasing the stream power of the slope runoff. 

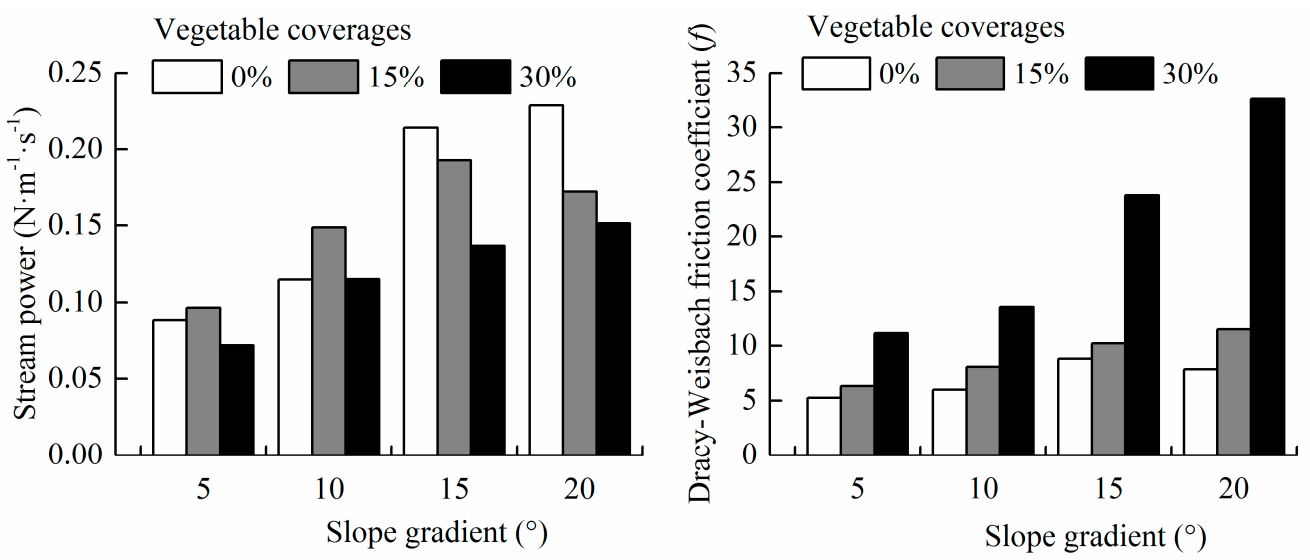

Figure 7. Effects of riparian vegetation on the stream power and the Dracy-Weisbach friction coefficient under different slope gradients.

As shown in Figure 7, the friction coefficient increased with the slope gradient, which was consistent with a study by Zhao et al. [37]. Due to different experimental conditions and precisions, the relationship between slope runoff friction and the slope gradient was controversial in different studies, and explains the different outcomes of each study $[33,47,48]$. According to the mathematical formula (2), the friction coefficient was mainly affected by the flow depth, the slope flow velocity of the surface, and the slope gradient. In our study, the increase of the slope gradient on the friction coefficient increased much more than the reduction of the runoff depth and the flow velocity on the friction coefficient. Thus, the slope friction coefficient increased with the slope gradient. As mentioned above, the sand content of the sediment increased with the slope gradient, which indicates that although the increase of slope gradient harbors more energy for the flow, the energy consumption increased concurrently with the transport of the sediments. At the same slope gradient, the friction coefficient increased with increasing vegetation coverage. The average friction coefficients of the bare slope, $15 \%$ and $30 \%$ vegetation coverage were $6.99,9.06$ and 30.02, respectively, indicating that vegetation can effectively increase slope friction. The increase in vegetation coverage increases the energy consumption of the slope runoff to overcome the friction so that the energy of separating and transporting the soil particles is lower, resulting in a decrease in slope erosion and sediment yield. According to the stepwise regression that quantifies the relationship with vegetation coverage, slope gradient, and the interaction of the two on the hydraulic parameters of the slope, the following equations were observed (for vegetation slopes):

$$
\begin{gathered}
\omega=0.121 S^{0.507} V^{-0.37}, R^{2}=0.97, P<0.05, \\
f=0.21(S V)^{0.93}, R^{2}=0.87, P<0.05,
\end{gathered}
$$

where, $\omega$ is the stream power $\left(\mathrm{N} \cdot \mathrm{m}^{-1} \cdot \mathrm{s}^{-1}\right) ; f$ is the friction coefficient; $V$ is the vegetation coverage $(\%)$; $S$ is the slope gradient $\left({ }^{\circ}\right) ; S V$ is the interaction of the slope gradient and the vegetation coverage.

The stepwise regression results showed that the hydraulic characteristics of the slope were closely related to the slope gradient and vegetation coverage, and the stream power positively influenced the slope gradient and was negatively influenced by the vegetation coverage. The absolute value of the independent power exponent was used to characterize the contribution rate of the independent variable to the dependent variable. The results showed that the slope gradient contributed more to the change of stream power. The interaction between the slope gradient and vegetation coverage played a dominant role in the determination of the friction coefficient. The results show that vegetation increases slope friction and reduces the runoff erosivity, but vegetation coverage was not an independent factor affecting slope erosion. When the slope gradient was greater than a certain value, the vegetation inhibition of runoff erosion was relatively small [16,33]. 
The Grey correlation analysis method was used to obtain the Grey correlation value of the slope hydraulic characteristics and the slope erosion rate (Table 2). The value of the correlation degree indicates the effect of each factor on the slope erosion rate [35]. The results show that the correlation degree between erosion rate and the stream power of bare slopes was greater than that between the erosion rate and friction coefficient, indicating the dominant function of stream power in the erosion process. Therefore, the bare slope has a larger sediment yield during the slope erosion process. However, for the two vegetation slopes ( $15 \%$ and $30 \%$ coverage), the correlation degree between stream power and erosion rate was smaller than that between friction coefficient and erosion rate. The friction coefficient played a dominant role in the erosion process, and the slope sediment yield reduced. During the slope erosion process, when the coverage of the slope's vegetation increased, the friction coefficient increased, while the stream power decreased. In addition, vegetation enhances the erosion resistance of the slope's soil [15] and effectively inhibits soil slope erosion. Thus, the greater the vegetation coverage, the stronger the effect is $[14,16]$.

Table 2. Grey correlation between the slope hydraulic characteristics and the slope erosion rate.

\begin{tabular}{ccc}
\hline \multirow{2}{*}{ Vegetation Coverage } & \multicolumn{2}{c}{ Correlation Degree } \\
\cline { 2 - 3 } & Stream Power & Friction Coefficient \\
\hline Bare & 0.85 & 0.80 \\
15\% vegetation coverage & 0.85 & 0.89 \\
$30 \%$ vegetation coverage & 0.81 & 0.86 \\
\hline
\end{tabular}

\subsection{Contribution of the Slope Gradient to the Inhibiting Effect of Riparian Vegetation on the Erosion Rate}

Based on the above results, we further analyzed the contribution of slope gradient to the inhibiting ability of riparian vegetation on the erosion rate. As shown in Figure 8, at 15\% vegetation coverage and a slope gradient of $<8^{\circ}$, the erosion rate was affected by vegetation coverage; however, the inhibiting effect of vegetation on the erosion rate decreased with an increasing slope gradient. When the slope was $>8^{\circ}$, the contribution of the slope gradient to the erosion rate was greater than the vegetation coverage. The contribution of the slope gradient to the erosion rate increased with a higher slope gradient. However, at $30 \%$ vegetation coverage, when the slope was $>11^{\circ}$, the contribution of the slope gradient to the erosion rate was greater than vegetation coverage, indicating that the increasing vegetation coverage can effectively increase the slope gradient that is critical for slope erosion. In general, riparian vegetation inhibited slope erosion and sediment yield. However, when the slope gradient was greater than a certain value, the effect of vegetation on sediment was weaker, suggesting that in order to better conserve soil and water, we need different riparian vegetation coverage on slopes with varying gradients. Of note is that the slope runoff and sediment yield was affected by rainfall and infiltration. On one hand, the soil infiltration rate decreased with an increasing slope gradient, resulting in more rainfall being converted into runoff; on the other hand, the increase of slope gradient would lead to the decrease of slope rainfall, which in turn reduced slope runoff [38,39]. This indicates that the relationship between slope runoff and slope gradient is complex. In our study, the critical value of slope gradient which affected runoff and sediment were different. Based on previous studies $[49,50]$ increasing vegetation coverage reduced runoff and sediments, but there was also a critical value, when a certain degree of coverage was reached and increases of vegetation coverage did not result in obvious inhibiting effects. For example, Zhu et al. [50] showed when the vegetation coverage was $<60 \%$, the runoff and sediment yield gradually decreased with increases of vegetation coverage. When vegetation coverage reached more than $80 \%$, an increase in the vegetation coverage did not result in any additional obvious inhibiting effects on runoff and sediment yield. However, these studies only examined the vegetation coverage in soil and water conservation and did not take the impact of slope gradient on the inhibiting effects of vegetation on slope erosion and sediment yield into consideration. In our study, we combined these two factors (slope gradient and vegetation coverage) to investigate 
the predominant factor in soil erosion, and determined the limit of slope gradient on the inhibiting effects of vegetation on slope erosion and sediment yield. This is different from previous studies on soil erosion characteristics of natural slopes $[14,21,23,26]$. In addition to the slope gradient, the inhibiting effect of vegetation on slope erosion was also affected by rainfall characteristics, stream types and soil properties, as well as the vegetation type, pattern, location, roots and canopy $[15,17-19]$. Therefore, it is necessary to investigate the relationship between vegetation and soil erosion from various aspects and consider external factors, in order to effectively strengthen the soil and water conservation of riparian vegetation.
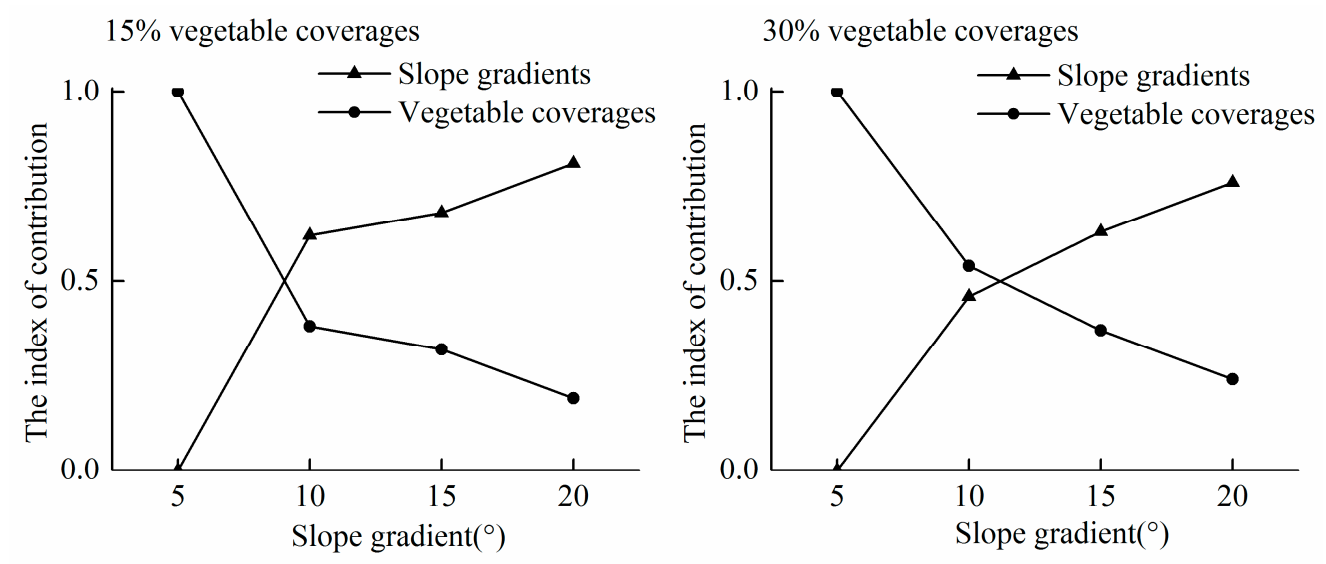

Figure 8. Contribution of slope gradient to the erosion rate under different vegetation coverage.

\section{Conclusions}

(1) The presence of vegetation can reduce the slope runoff rate and sediment yield, and as the vegetation coverage increased, the runoff rate and erosion rate decreased. The slope gradient influences the slope runoff and sediment yield, but acts in different ways. The runoff rate decreased with higher slope gradients. But the erosion rate reached its peak at a slope gradient of $15^{\circ}$.

(2) There was a critical value of vegetation coverage for inhibiting eroded sediments, which was influenced by the degree of slope gradient. Increasing the vegetation coverage increases the critical value of the inhibiting effect. At $15 \%$ vegetation coverage, when the slope gradient was $<8^{\circ}$, the vegetation notably inhibited the slope sediment yield; while at $30 \%$ vegetation coverage, when the slope gradient was $<11^{\circ}$, the vegetation notably inhibited the slope sediment yield.

(3) At different vegetation coverage, clay and fine silts were always preferentially transported by the runoff first, and there was no notable change in the particle size of the eroded sediments, which were mainly clay and silts. The increase in slope gradient led to the enhancement of slope runoff to transport sediments, resulting in coarse silts enriched at a slope gradient of $20^{\circ}$.

(4) Hydraulic characteristics were closely related to the slope gradient and vegetation coverage. Stream power increases with slope gradient by a power function, but negatively correlates with vegetation coverage. The friction coefficient was mainly dominated by the interaction of slope gradient and vegetation coverage in a power function relationship.

(5) Grey correlation analysis revealed that with the increase of vegetation coverage the influence of stream power on slope sediment yield was weakened, while the influence of the friction coefficient was enhanced.

Overall, the inhibiting effect of riparian vegetation on slope erosion is a complex physical process that involves multiple factors. The results of our study can provide reference for studying the mechanism of riparian vegetation buffer belts to control soil erosion. 
Author Contributions: Conceptualization, Y.Z. and Q.Z.; methodology, Y.Z.; software, Y.Z. and Z.C.; formal analysis, Y.Z.; investigation, Y.Z., Q.Z., and Z.C.; resources, Q.Z. and S.D.; writing-original draft preparation, Y.Z.; writing—review and editing, Y.Z., Q.Z. and S.D.; visualization, Y.Z.; funding acquisition, Q.Z. and S.D.

Funding: This research was funded by the National Natural Sciences Foundation of China (U1804119, 41301197, 41771202), the Colleges and Universities Key Scientific Research Projects of Henan Province (18A170004), and the Science and Technology Project of Henan Province (192102310304).

Conflicts of Interest: The authors declare no conflict of interest.

\section{References}

1. Fu, B.; Li, Y.; Wang, Y.; Zhang, B.; Yin, S.; Zhu, H.; Xing, Z. Evaluation of ecosystem service value of riparian zone using land use data from 1986 to 2012. Ecol. Indic. 2016, 69, 873-881. [CrossRef]

2. Feld, C.K.; Fernandes, M.R.; Ferreira, M.T.; Hering, D.; Ormerod, S.J.; Venohr, M.; Gutiérrez-Cánovas, C. Evaluating riparian solutions to multiple stressor problems in river ecosystems-A conceptual study. Water Res. 2018, 139, 381-394. [CrossRef] [PubMed]

3. González, E.; Felipe-Lucia, M.R.; Bourgeois, B.; Boz, B.; Nilsson, C.; Palmer, G.; Palmer, A.A. Integrative conservation of riparian zones. Biol. Conserv. 2018, 211, 20-29. [CrossRef]

4. $\quad$ Oles, K.M.; Weixelman, D.A.; Lile, D.F.; Tate, K.W.; Snell, L.K.; Roche, L.M. Riparian meadow response to modern conservation grazing management. Environ. Manag. 2018, 60, 383-395. [CrossRef] [PubMed]

5. Turunen, J.; Aroviita, J.; Marttila, H.; Louhi, P.; Laamanen, T.; Tolkkinen, M.; Luhta, P.L.; Kløve, B.; Muotka, T. Data from: Differential responses by stream and riparian biodiversity to in-stream restoration of forestry-impacted streams. J. Appl. Ecol. 2018, 54, 1505-1514. [CrossRef]

6. Zhang, C.; Li, S.; Qi, J.; Xing, Z.; Meng, F. Assessing impacts of riparian buffer zones on sediment and nutrients loading into streams at watershed scale using an integrated REMM-SWAT model. Hydrol. Process. 2018, 31, 916-924. [CrossRef]

7. Schoonover, J.E.; Crim, J.F.; Williard, K.W.J.; Groninger, W.J.; Zaczek, J.J.; Pattumma, K. Sediment dynamics within buffer zone and sinkhole splay areas under extreme soil disturbance conditions. Environ. Manag. 2015, 56, 618-629. [CrossRef] [PubMed]

8. Whigham, D.F.; Walker, C.M.; Maurer, J.; King, R.S.; Hauser, W.; Baird, S.; Keuskamp, J.A.; Neale, P.J. Watershed influences on the structure and function of riparian wetlands associated with headwater streams-Kenai Peninsula, Alaska. Sci. Total Environ. 2017, 599-600, 124-134. [CrossRef]

9. Nagy, R.C.; Porder, S.; Neill, C.; Brando, P.; Quintino, R.M.; Nascimento, S.A.D. Structure and composition of altered riparian forests in an agricultural Amazonian landscape. Ecol. Appl. 2015, 25, 1725-1738. [CrossRef]

10. Hubble, T.C.T.; Docker, B.B.; Rutherfurd, I.D. The role of riparian trees in maintaining riverbank stability: A review of Australian experience and practice. Ecol. Eng. 2010, 36, 292-304. [CrossRef]

11. Politti, E.; Bertoldi, W.; Gurnell, A.; Henshaw, A. Feedbacks between the riparian Salicaceae and hydrogeomorphic processes: A quantitative review. Earth Sci. Rev. 2018, 176, 147-165. [CrossRef]

12. Hould-Gosselin, G.; Rousseau, A.N.; Gumiere, S.J.; Hallema, D.W.; Ratté-Fortin, C.; Thériaul, G.; Bochove, E.V. Modeling the sediment yield and the impact of vegetated filters using an event-based soil erosion model-a case study of a small Canadian watershed. Hydrol. Process. 2016, 30, 2835-2850. [CrossRef]

13. Srivastava, N.K.; Ram, L.C.; Masto, R.E. Role of selected riparian herbs in reducing soil erosion and nutrient loss under simulated rainfall. Environ. Earth Sci. 2010, 61, 405-417. [CrossRef]

14. Xia, X.; Xin, Z.; Zhao, Y.; Kong, Q. Soil and water conservation benefits of riparian vegetation in Beijing mountainous area. J. Soil Water Conserv. 2018, 32, 71-77. (In Chinese) [CrossRef]

15. Li, Q.; Liu, G.; Zhang, Z.; Tuo, D.; Bai, R.; Qiao, F. Relative contribution of root physical enlacing and biochemistrical exudates to soil erosion resistance in the loess soil. Catena 2017, 153, 61-65. [CrossRef]

16. Zhao, C.; Gao, J.; Huang, Y.; Wang, G.; Zhang, M. Effects of vegetation stems on hydraulics of overland flow under varying water discharges. Land Degrad. Dev. 2016, 27, 748-757. [CrossRef]

17. Hou, J.; Wang, H.; Fu, B.; Zhu, L.; Wang, Y.; Li, Z. Effects of plant diversity on soil erosion for different vegetation patterns. Catena 2016, 147, 632-637. [CrossRef]

18. Zhang, X.; Li, P.; Li, Z.; Yu, G.Q.; Li, C. Effects of precipitation and different distributions of grass strips on runoff and sediment in the loess convex hillslope. Catena 2018, 162, 130-140. [CrossRef] 
19. Okin, G.S.; Heras, M.M.; Saco, P.M.; Throop, H.L.; Vivoni, E.R.; Parsons, A.J.; Wainwright, J.; Peters, D.P. Connectivity in dryland landscapes: Shifting concepts of spatial interactions. Front. Ecol. Environ. 2015, 13, 20-27. [CrossRef]

20. Stefano, C.D.; Ferro, V. Testing sediment connectivity at the experimental SPA2 Basin, Sicily (Italy). Land Degrad. Dev. 2017, 28, 1992-2000. [CrossRef]

21. Jiang, F.; Huang, Y.; Wang, M.; Lin, J.; Zhao, G.; Ge, H. Effects of rainfall intensity and slope gradient on steep colluvial deposit erosion in Southeast China. Soil Sci. Soc. Am. J. 2014, 78, 1741-1752. [CrossRef]

22. Shen, H.; Zheng, F.; Wen, L.; Han, Y.; Hu, W. Impacts of rainfall intensity and slope gradient on rill erosion processes at loessial hillslope. Soil Tillage Res. 2016, 155, 429-436. [CrossRef]

23. Zhao, Q.; Ji, X.; Xu, S.; Wu, C. Inhibiting effect of riparian vegetation on erosion and sediment yield on slope runoff. Trans. Chin. Soc. Agric. Eng. 2018, 34, 170-178. (In Chinese) [CrossRef]

24. Liu, D.; She, D.; Yu, S.; Shao, G.; Chen, D. Rainfall intensity and slope gradient effects on sediment losses and splash from a saline-sodic soil under coastal reclamation. Catena 2015, 128, 54-62. [CrossRef]

25. Defersha, M.B.; Quraishi, S.; Melesse, A. The effect of slope steepness and antecedent moisture content on interrill erosion, runoff and sediment size distribution in the highlands of Ethiopia. Hydrol. Earth Syst. Sci. 2011, 7, 2367-2375. [CrossRef]

26. Liu, Q.; Zhu, B.; Tang, J.; Huang, W.; Zhang, X. Hydrological processes and sediment yields from hillslope croplands of regosol under different Slope Gradients. Soil Sci. Soc. Am. J. 2017, 81, 1517-1525. [CrossRef]

27. Zhao, Q.; Liu, Q.; Ma, L.; Ding, S.; Lu, X.; Zhang, Y.; Cao, Z. Spatial-temporal dynamics of vegetation pattern in a typical riparian buffer zone of the middle and lower reaches of Yellow River. Chin. J. Ecol. 2017, 36, 2127-2137. (In Chinese) [CrossRef]

28. Cao, Z.; Zhao, Q.; Ding, S.; Zhang, Y.; Liu, P.; Wu, C. Effect of slope gradient and vegetation cover on sediment yielding characteristics of the riparian slope. J. Nat. Resour. 2017, 32, 1892-1904. (In Chinese) [CrossRef]

29. Meng, H.; Zhao, T.; Zhang, H.; Xu, H. Study on characteristics of runoff and non-point source pollution in Mengjin flood plain of Yellow River. J. Soil Water Coserv. 2008, 22, 48-51. (In Chinese) [CrossRef]

30. Zhao, T.; Xu, H.; Ren, Y.; Zeng, F.; Tai, C. Research progress in agricultural non-point nitrogen pollution control in riparian wetlands. Chin. J. Environ. Eng. 2008, 2, 1441-1446. (In Chinese)

31. Li, G.; Abrahams, A.D.; Atkinson, J.F. Correction factors in the determination of mean velocity of overland flow. Earth Surf. Proc. Land 1996, 21, 509-515. [CrossRef]

32. Xiao, H.; Liu, G.; Liu, P.; Zheng, F.; Zhang, J.; Hu, F. Response of soil detachment rate to the hydraulic parameters of concentrated flow on steep loessial slopes on the Loess Plateau of China. Hydrol. Process. 2017, 31, 2613-2621. [CrossRef]

33. Pan, C.; Ma, L.; Wainwright, J.; Shangguan, Z. Overland flow resistances on varying slope gradients and partitioning on grassed slopes under simulated rainfall. Water Resour. Res. 2016, 52, 6414-6428. [CrossRef]

34. Defersha, M.B.; Melesse, A.M. Effect of rainfall intensity, slope and antecedent moisture content on sediment concentration and sediment enrichment ratio. Catena 2012, 90, 47-52. [CrossRef]

35. Wang, J.; Huang, J.; Wu, P.; Zhao, X. Application of neural network and grey relational analysis in ranking the factors affecting runoff and sediment yield under simulated rainfall. Soil Res. 2016, 54, 291-301. [CrossRef]

36. Wang, L.; Shi, Z. Size selectivity of eroded sediment associated with soil texture on steep slope. Soil Sci. Soc. Am. J. 2015, 79, 917-929. [CrossRef]

37. Zhao, Q.; Li, D.; Zhuo, M.; Guo, T.; Liao, Y.; Xie, Z. Effects of rainfall intensity and slope gradient on erosion characteristics of the red soil slope. Stoch. Environ. Res. Risk A 2015, 29, 609-629. [CrossRef]

38. Chen, L.; Young, M. Green-Ampt infiltration model for sloping surfaces. Water Resour. Res. 2006, 42, 887-896. [CrossRef]

39. Zhang, H.; Zheng, F. Effect of slope gradient on erosion from a red soil hillslope under different rainfall intenisty. J. Soil Water Coserv. 2011, 25, 40-43. (In Chinese) [CrossRef]

40. Wu, S.; Yu, M.; Chen, L. Non-monotonic and spatial-temporal dynamic slope effects on soil erosion during rainfall-runoff processes. Water Resour. Res. 2017, 53, 1369-1389. [CrossRef]

41. Papanicolaou, A.N.; Abban, B.K.B.; Dermisis, D.C.; Giannopoulos, C.P.; Flanagan, D.C.; Frankenberger, J.R.; Wacha, K.M. Flow resistance interactions on hillslopes with heterogeneous attributes: Effects on runoff hydrograph characteristics. Water Resour. Res. 2018, 54, 359-380. [CrossRef]

42. Kulasova, A.; Blazkova, S.; Beven, K.; Rezacova, D.; Cajthaml, J. Vegetation pattern as an indicator of saturated areas in a Czech headwater catchment. Hydrol. Process. 2014, 28, 5297-5308. [CrossRef] 
43. Vaezi, A.R.; Zarrinabadi, E.; Auerswald, K. Interaction of land use, slope gradient and rain sequence on runoff and soil loss from weakly aggregated semi-arid soils. Soil Till. Res. 2017, 172, 22-31. [CrossRef]

44. Mahmoodabadi, M.; Sajjadi, S.A. Effects of rain intensity, slope gradient and particle size distribution on the relative contributions of splash and wash loads to rain-induced erosion. Geomorphology 2016, 253, 159-167. [CrossRef]

45. Shi, Z.; Yue, B.; Wang, L.; Fang, N.; Wang, D.; Wu, F. Effects of mulch cover rate on interrill erosion processes and the size selectivity of eroded sediment on steep slopes. Soil Sci. Soc. Am. J. 2012, 77, 257-267. [CrossRef]

46. Zhang, G.; Liu, G.; Wang, G.; Wang, Y. Effects of vegetation cover and rainfall intensity on sediment-bound nutrient loss, size composition and volume fractal dimension of sediment particles. Pedosphere 2011, 21, 676-684. [CrossRef]

47. Smith, M.W.; Cox, N.J.; Bracken, L.J. Applying flow resistance equations to overland flow. Prog. Phys. Geogr. 2007, 31, 363-387. [CrossRef]

48. Zhang, G.; Luo, R.; Cao, Y.; Shen, R.; Zhang, X. Impacts of sediment load on manning coefficient in supercritical shallow flow on steep slopes. Hydrol. Process. 2010, 24, 3909-3914. [CrossRef]

49. Zhang, Q.; Wang, Z.; Wang, D.; Liu, J. Advances in researches of the effects of grassland vegetation on soil erosion in Loess Plateau. Adv. Earth Sci. 2017, 32, 1093-1101. (In Chinese)

50. Zhu, B.; Li, Z.; Li, P.; You, Z. Effect of grass coverage on sediment yield of rain on slope. Acta Pedol. Sin. 2010, 47, 401-407. (In Chinese) [CrossRef]

(C) 2019 by the authors. Licensee MDPI, Basel, Switzerland. This article is an open access article distributed under the terms and conditions of the Creative Commons Attribution (CC BY) license (http://creativecommons.org/licenses/by/4.0/). 